\title{
Devletin Dinî Alanı Düzenlemesi Bağlamında Fransa ve Türkiye'de İki Kanun: 1901 Dernekler Kanunu ile 1925 Tekke, Zaviye ve Türbedarlıkların Kapatılmasına İlişkin Kanun
}

\author{
Mesut Düzce \\ Dr. Öğr. Üyesi, Van Yüzüncü Yll Üniversitesi (ROR ID: 041jyzp61) \\ İlahiyat Fakültesi, Din Sosyolojisi Anabilim Dalı \\ Assistant Professor Dr., Van Yuzuncu Yil University, Faculty of Divinty, Department of Sociology of Religion \\ Van/Turkey \\ mesutduzce@yyu.edu.tr \\ ORCID: 0000-0001-8599-390X
}

\section{Two Laws in France and Turkey in the Context of the State's Regulation of Religious Space: 1901 Law on Associations and 1925 Law on the Closure of Dervishes, Lodges and Zawiyas}

\begin{abstract}
One of the important features of the law is that allows the legislator to regulate the social sphere, albeit to a certain extent. The ruling elites, who use the power of the state, have frequently applied this opportunity to build a society in line with their ideations. Based on the understanding that the state should dominate religion, some regulations made into the social sphere merge as an extension of this understanding. It is possible to see such regulations in almost all examples of authoritarian regimes. The desire to re-establish the society with a new content requires the liquidation of the institutions to be shaped according to the legitimacy patterns of the old order. Although the society possess the old society characteristics and continues to have the old sense of legitimacy, the new owners of power are not willing to adopt this sense of legitimacy. In the perspective of the new owners of the regime, the institutions of the old order constitute a point of resistance to the construction of the new order, this situation blocks the possibility of shaping and managing the society according to their own approach. From this viewpoint, it becomes possible to read the steps taken by the state in regulating the religious sphere as an authoritarian mentality's quest to reshape society and make it manageable by itself. However, this point needs to be justified. To meet this need in countries where there are ruling elites who want to implement an authoritarian secularization program or project, the current religious understanding, which is largely influenced by society, is often portrayed as a phenomenon that is anti-modernity, and therefore against science, progress and reason. In such cases, religion and its associated structures are often subjected to "superstition",
\end{abstract}

İntihal Taraması/Plagiarism Detection: Bu makale intihal taramasından geçirildi/This paper was checked for plagiarism Geliş/Received: 12 Nisan/April 2020 | Kabul/Accepted: 08 Temmuz/July 2020|Yayın/Published: 20 Eylül/September 2020 Atıf/Cite as: Mesut Düzce, “Devletin Dinî Alanı Düzenlemesi Bağlamında Fransa ve Türkiye'de İki Kanun: 1901 Dernekler Kanunu ile 1925 Tekke, Zaviye ve Türbedarlıkların Kapatılmasına İlişkin Kanun = Two Laws in France and Turkey in the Context of the State's Regulation of Religious Space: 1901 Law on Associations and 1925 Law on the Closure of Dervishes, Lodges and Zawiyas", Eskiyeni 42 (Eylül/September 2020), 1029-1050. https://doi.org/10.37697/eskiyeni.718989 Copyright @ @ Anadolu İlahiyat Akademisi/Anatolian Theological Academy, 06050, Ankara, Turkey | www.anilakademi.com CC BY-NC 4.0 | This paper is licensed under a Creative Commons Attribution-NonCommercial License 
"reactionary", "a pile of superstitions", "irrational" and many other negative attributes. Therefore, religion, in this perspective, appears to be the principal obstacle to progress and science, that is, to be the main responsible for the decline. This provides an opportunity for the ruling elite to "justify" the legal arrangements in this area.

Choosing to rule the state with an authoritarian mindset also brings about the establishment of a dominant state-society relationship. In this relationship, in which a one-way hierarchical structure is in favor of the state, the state, and of course the political elite that governs it, becomes the owner and norm-maker of society. This norm says that the decision-making authority on how and what the quality of society should belong to the state and its rulers. In other words, state-society regulations are fictionalized on a hierarchical basis; and supremacy in the hierarchy is attributed to the state. For this reason, authoritarian regimes carry out their arrangements in the social sphere from this perspective. This study focuses on two laws in the French Third Republic and one-party-ruled Turkey, which are cited among such authoritarian regimes in terms of religioncommunity relations and as a result of state' attempt to take over the function of religion in society. The evaluation of France in general, especially the Third Republic, as a role model for Turkey during its founding period, has inspired this work as well as many other studies. In this context, the law of Associations issued in France in 1901 on the reorganization of religious associations, and the law regarding the closure of Dervish Lodges, Zawiya and Shrines in Turkey in 1925 are discussed. Although both laws have been passed for a long time, these laws still remain in the focus of political conflicts and legal debate. This is thought to be due, significantly, to the fact that these laws are related to a sensitive issue such as regulating religious activities of the public authority. On the other hand, the main reason for the struggle against religious institutions such as church in France and dervish lodges, zawiya and shrines in Turkey is that they have one of the most powerful and privileged positions of the old order and are seen as a major obstacle to Republican projects. As in most other nation-states, such as Turkey and France, the main issue for Republicans is to produce citizens for the Republic. From the point of view of the Republican elites, it is clear that this can only be achieved in the institutions of the new order, so the institutions of the old order are a major obstacle to this. The state's domination of education and the achievement of national unity through education can also be seen as an output of this idea. The republic cannot remain a spectator from institutions that it has not approved, to receive education of their own children and divide their souls. By monopolizing education by the state, generations that will be raised in line with the ideology of the Republicans will spread the influence of rejectable understandings. Thus, citizens would not be only raised as free individuals, but the threat of the ancient regime would also be largely eliminated.

Although we do not claim that these two laws are exactly the same, our study points out that the concerned laws contain similar qualities and that the understanding and justifications laid out in their construction have common characteristics. In general, after the revolution of 1789, the arrangements made by the state in France regarding the religious aspects such as the development of policies to control the religious area, pushing religion out of the public sphere, subjecting religion-related elements as irrational, anti-progress, superstition, superstition belief, sometimes threaten national sovereignty and integrity were the inspiration for the ruling elite in the early years of the Republic of Turkey. It is, therefore, accepted by many researchers and observers that the two countries, in this respect, have comparable qualifications. The study, from a comparative perspective, deals with the developments that occurred with the enforcement of laws in both countries and how the relevant sectors were affected.

\section{Keywords}

Sociology of Religion, State, France, Religious Associations, Turkey, Dervish Lodge and Zawiyas 


\section{Devletin Dinî Alanı Düzenlemesi Bağlamında Fransa ve Türkiye'de İki Kanun: 1901 Dernekler Kanunu ile 1925 Tekke, Zaviye ve Türbedarlıkların Kapatılmasına İlişkin}

\section{Kanun}

\section{Öz}

Yasaların önemli özelliklerinden bir tanesi, yasa koyucuya toplumsal alanı, belli ölçülerde de olsa, düzenleme olanağı sağlamasıdır. Devletin gücünü kullanan iktidar elitleri, tarih boyunca kendi tasavvurları doğrultusunda bir toplum inşa etmek için bu olanağa sıklıkla müracaat etmişlerdir. Dinin devletin kontrolü altında tutulması, başka bir ifade ile devletin dine hâkim olması gerektiği anlayışından hareketle toplumsal alanla ilgili birtakım düzenlemeler de bu anlayışın uzantısı olarak karşımıza çıkmaktadır. Bu tür düzenlemeleri otoriter rejimlerin olduğu hemen hemen bütün örneklerde görmek mümkündür. Toplumun yeni bir içerikle yeniden kurulması isteği, eski düzenin meşruiyet kalıplarına göre şekillenmiş kurumlarının tasfiye edilmesini gerektirmektedir. Çünkü toplum, her ne kadar eski toplum olsa ve eski meşruiyet anlayışına sahip olmaya devam etse de iktidarın yeni sahipleri bu meşruiyet anlayışını benimsemekte pek istekli davranmamaktadır. Dolayısıyla rejimin yeni sahipleri nazarında eski düzenin kurumları yeni düzenin inşa edilmesi konusunda bir direnç noktasını teşkil etmekte olduğu için bu durum onların toplumu kendi zihniyetleri doğrultusunda şekillendirme ve yönetme imkânının önünü tıkamaktadır. Bu açıdan bakıldığında, dinî alanı düzenlemesine ilişkin devletin attığı adımları, temelde otoriter zihniyetin toplumu yeniden şekillendirme ve kendisi tarafindan yönetilebilir hale getirme arayışı olarak okumak mümkün hale gelmektedir. Ancak bunun gerekçelendirilerek meşrulaştırılması ihtiyacı da ortadadır. Bu ihtiyacı karşılamak için, otoriter bir sekülerleşme programı ya da projesini uygulamak isteyen yönetici elitlerin bulunduğu ülkelerde, toplumun büyük oranda etkisinde olduğu mevcut dinî anlayış, genellikle modernite karşıtı, bu nedenle de bilim, ilerleme ve akla karşı bir olgu biçiminde tasvir edilmektedir. Bu tür durumlarda din ve onunla ilişkili yapılar, genellikle "batıl inanç", “gericilik”, "hurafeler yığını", “akıldışı” ve buna benzer birçok olumsuz nitelemelere maruz kalmaktadır. Dolayısıyla din, bu perspektifte, ilerlemenin ve bilimin önündeki engel, yani gerilemenin esas sorumlusu olarak tebarüz etmektedir. Bu durum, yönetici elite bu alandaki yasal düzenlemeleri "haklılaştıran” bir imkân sunmaktadır.

Devleti otoriter bir zihniyetle yönetmenin tercih edilmesi, tahakkümcü bir devlet-toplum ilişkisinin yerleşmesini de beraberinde getirmektedir. Devlet lehine tek yönlü bir hiyerarşik yap1nın hâkim olduğu bu ilişkide devlet ve elbette onu yöneten siyasi elit, toplumun sahibi ve norm koyucusu haline gelmektedir. Bu norm toplumun niteliğinin nasıl ve ne olması gerektiğine ilişkin karar merciinin devlet ve onu yönetenlere ait olduğunu salık vermektedir. Başka bir ifadeyle, devlet-toplum düzenlemeleri hiyerarşik bir temelde kurgulanmış ve hiyerarşide üstünlük devlete atfedilmiştir. Bu nedenle otoriter rejimler, hâkim oldukları hemen hemen bütün yerlerde toplumsal alana ilişkin giriștikleri düzenlemeleri bu tarz bir mantığın içinden gerçekleştirmektedir. Bu çalışmada da bu tür otoriter rejimler arasında görülen Fransız Üçüncü Cumhuriyeti ile tek-parti yönetiminin iktidarda olduğu Türkiye Cumhuriyeti’nde din-toplum ilişkileri açısından, devletin din-toplum alanında düzenleyici bir işlev üstlenme girişiminin bir sonucu olarak çıarılan iki yasaya odaklanmaktadır. Genel olarak Fransa'nın, özellikle de Üçüncü Cumhuriyet'in, kuruluş dönemi Türkiye'si için bir rol model olarak değerlendirilmesi, başka pek çok çalışmanın olduğu gibi, bu çalışmanın da ilham kaynağı olmuştur. Bu bağlamda, Fransa'da dinî derneklerin yeniden düzenlenmesine ilişkin çıkarılan 1901 Dernekler Kanunu ile Türkiye'de 1925 tarihinde Tekke, Zaviye ve Türbelerin Kapatılmasına ilişkin kanun ele alınmaktadır. Her iki yasanın da üzerinden uzunca bir zaman geçmiş olmasına rağmen bu yasalar hâlâ 
siyasi çekişmelerin ve hukuksal tartışmaların odağında yer almaya devam etmektedir. Bu durumun, önemli ölçüde, bu yasaların kamu otoritesinin dinî faaliyetleri düzenleme gibi hassas bir konuyla ilişkili olmasından kaynaklandığı düşünülmektedir.

Öte yandan, gerek Fransa'da Kilise ve dinî derneklere, gerekse Türkiye'de tekke, zaviye ve tarikatlara karşı yürütülen mücadelenin asıl sebebi onları eski düzenin en güçlü ve ayrıcalıklı pozisyonlarından birine sahip olmaları ve Cumhuriyetçi projelerin önünde büyük bir engel olarak görülmeleridir. Diğer ulus-devletlerin çoğunda olduğu gibi, Türkiye ve Fransa'da da cumhuriyetçiler için temel mesele cumhuriyete yurttaşüretmektir. Cumhuriyetçi elit açısından, bunun ancak kurulan yeni düzenin kurumlarında gerçekleştirilebileceği, dolayısıyla eski düzenin kurumlarının bunun önünde büyük bir engel olduğu açıktır. Devletin eğitim alanını hâkimiyetine alması ve eğitimde birliktelik sağlamaya çalışması da bu düşüncenin bir ürünü olarak görülebilir. Cumhuriyet kendi çocuklarının, tasvip etmediği kurumlardan eğitim almalarına ve ruhlarının bölünmesine seyirci kalamaz. Eğitimin devletin tekeline alınmasıyla, Cumhuriyetçilerin ideolojisi doğrultusunda yetiştirilecek nesiller onaylanmayan anlayışların kıskacına girmekten kurtulmuş olacaklardır. Böylece hem vatandaşlar özgür bireyler olarak yetişecek hem de devri sabık olarak nitelenen tehdit büyük ölçüde bertaraf edilmiş olacaktı.

Çalışmamız, her ne kadar bu iki yasanın birebir aynı olduğu iddiasında olmasa da, söz konusu yasaların benzer nitelikleri içerdiği ve onların kurgulanmasında ortaya konan anlayışın ve gerekçelerin ortak özelliklere sahip olduğu noktasından hareket etmektedir. Genel olarak, Fransa'da 1789 Devriminden sonra devletin dinî alanı kontrol etmeye yönelik politikalar geliştirilmesi, dinin kamusal alanın dışına itilmesi, din ile ilişkili unsurların kimi zaman akıl dışı, ilerleme karşıtı, hurafe, batıl inanç gibi nitelemelere konu edilmesi kimi zaman da ulusal egemenliği ve bütünlüğü tehdit edici bir unsur olarak görülmesi gibi durumların Türkiye Cumhuriyeti'nin ilk yıllarındaki yönetici elit için ilham kaynağı olduğu, iki ülkenin bu açıdan karşılaştırılabilir niteliklere sahip olduğu pek çok araştırmacı ve gözlemci tarafından teslim edilmektedir. Çalışmada, mukayeseli bir bakış açısıyla, her iki ülkede de yasaların yürürlüğe girmesiyle birlikte yaşanan gelişmeler ve ilgili kesimlerin nasıl etkilendiği ele alınmaktadır.

\section{Anahtar Kelimeler}

Din Sosyolojisi, Devlet, Fransa, Dinî Dernekler, Türkiye, Tekke ve Zaviyeler

\section{Giriş}

Otoriter bir sekülerleşme programı ya da projesini uygulamak isteyen yönetici elitlerin bulunduğu ülkelerde din, modernite karşıtı bir olgu biçiminde tasvir edilmektedir. Bu tür durumlarda din ve onunla ilişkili yapılar, genellikle "batıl inanç", "gericilik”, "hurafeler yığını”, "akıldışı” ve buna benzer birçok olumsuz nitelemelere maruz kalmaktadır. Bu tarz değerlendirmelerin oldukça kullanışlı işlevsel bir yönü bulunmaktadır. Dinin etkisini azaltmak ve onu kendi kontrolü altında tutmak isteyen seküler yönetici elitlerin toplumsal hayatı düzenlemeye girişirken bu gibi nitelemelere sıklıkla başvurdukları görülmektedir. Böylece dinin devletin kontrolü altında tutulması başka bir ifade ile devletin dine hâkim olmasının yolu açılmakta ve devletin din ve toplumsal alanla ilgili düzenlemeler yapması kolaylaşmaktadır.

Bu tür düzenlemelere girişilmesinin temelinde toplumun devletin öngördüğü bir modele doğru yönlendirilmesi, gerektiğinde zorlanması, başka bir ifade ile mev- 
cut toplumu "olması gereken toplum" haline getirme amacı yatmaktadır. Çünkü devletin otoriter zihniyeti, toplumun nasıl bir kimliğe sahip olması gerektiğine devletin karar verme hakkına sahip olduğu ilkesinden hareket etmektedir. Bu anlayış toplumu belirleme ve şekillendirme konusunda tek güç ve merci olarak devleti görmektedir. Buradan türeyen siyaset ise kamusal alanın tasvip edilmeyen toplumsal taleplerden arındırılması veya kontrol altında tutulmasını ima etmektedir. Bu amacı gerçekleştirebilmek için otoriter rejimler öngördükleri toplumsal düzene imkân verebilecek yasalar çıartma yoluna gitmektedirler.

Otoriter rejimlerin söz konusu olduğu hemen hemen bütün örneklerde toplumsal alanı düzenleme girişimleri görülebilmektedir. Bu çalışmada da bu tür otoriter rejimler arasında görülen Fransız Üçüncü Cumhuriyeti ile tek-parti yönetiminin iktidarda olduğu Türkiye Cumhuriyeti'nde din-toplum ilişkileri açısından toplumsal hayatı düzenlemeye matuf olarak çıkarılan birbirine benzer iki yasaya odaklanılmıştır. Fransa'nın genel olarak Türkiye için bir rol model olarak değerlendirilmesi çalı̧maya ilham kaynağı olmuştur. Bu bağlamda, Fransa'da dinî derneklerin yeniden düzenlenmesine ilişkin çıkarılan 1901 Dernekler Kanunu ile Türkiye'de 1925 tarihinde Tekke, Zaviye ve Türbelerin Kapatılmasına ilişkin kanun ele alınmaktadır. Çalışmada iki ülkede gerçekleştirilen düzenlemeler ayrı ayrı ele alındıktan sonra sonuç ve değerlendirme bölümünde bu düzenlemeler mukayeseli bir analize tabi tutulmaktadır.

\section{1901 Dernekler Kanunu ve Hukukî Temeli}

Fransa'da laisizm ve sekülerizm konusu genellikle 1789 Fransız Devrimiyle ilişkilendirilmektedir. Bu ilişkilendirmenin temelinde, devletin kilisenin mallarına el koyması yatmaktadır. Ancak, Fransa'da din ve devletin birbirinden kesin bir şekilde ayrılması için yaklaşık bir asır daha geçmesi gerekmiş ve bu alandaki gelişmeler Üçüncü Cumhuriyet'in ilanıyla birlikte ortaya çıkmaya başlamıştır. Bu dönemde pazar günleri için uygulanan çalışma yasağı 1880 tarihinde ve mezheplere ayrılan mezarlıklar 1881 tarihinde kaldırılırken 1884 tarihinde boşanma hukuku değiştirilmiş ve sivil evlilikler için boşanma yasası getirilmiştir.

Fransız laik eğitim sisteminde önemli bir yere sahip olan Lois Ferry ve Goblet laik bir okul sistemi oluşturup kilise kökenli eğitici personel yerine, sivil personel istihdam etme yoluna gitmişlerdir. Bu sürecin sonunda, en nihayet devlet ile kilisenin birbirinden kesin olarak ayrılması planlanmaktaydı ve bu, Loi Briand tarafindan 1905 tarihinde gerçekleştirilirken 1907 tarihinde çıkarılan ikinci bir kanun ile de uygulamaya konulmuştur. Laisizm, bu tarihten beri Fransız siyasetinde temel bir dogma olarak yer almaktadır (Antes, 2003, 10).

Dönemin Fransa'sındaki yasal duruma göre, dinî cemaatler varlıklarını cemaat statüsünde sürdürmeleri durumunda, dernekler halinde organize olmak durumunda kalacaklardı. Cemaatler bu durumda ya 'kültür dernekleri' veya sadece 'dernekler' olarak oluşturulan statülerden birine sahip olarak faaliyetlerini yürütebilecekti. Kültür dernekleri vergi bakımından birtakım imtiyazlara sahip olup, sadece dinî amaç 
güdebilir ve ancak uluslararası düzeyde yaygın olan dinler bu statüden faydalanabilirdi. Dernekler ise dinî faaliyetler yanında kültür ve eğitim gibi başka bazı faaliyetlerde de bulunma imkânına sahipti. Derneklerin, kültür derneklerine tanınan, vergi imtiyazları bulunmamaktaydı (Antes, 2003, 11).

Temelde din ve devlet arasına bir ayırım yapmayı ve özellikle dini, devletin uzağında tutmayı planlayan dönemin siyasi elitleri, 1901 tarihli Dernekler Kanunu ve 1905 tarihli Kilise-Devlet Ayırımı kanunu ile meselenin yasal zeminini oluşturma yoluna gitmişlerdir. Devr-i sabık olarak nitelenen Devrim öncesi Fransa'sında Katolik Kilisesi kralı kutsardı, karşılığında da Kral Katolikliği korur ve temsilcilerine de dünyevî ayrıcalıklar tanırdı. Bu durum 1789 Fransız Devrimi'ne kadar devam etti ancak Devrim hem monarşiyi lağvetmiş hem de Katolikliğin ayrıcalıklı konumuna son vermiştir. Ancak takip eden yıllarda bir alternatif oluşturulamaması, Fransa'da din-devlet ilişkilerinde bir belirsizliğin yaşanmasına sebep olmuştur. Bu belirsizlik ve yol açtı̆̆ kaotik durum devlet ile Kilise arasında Konkordato ismiyle bilinen 1801 tarihindeki anlaşmaya kadar devam etmiştir. 1905 tarihine kadar yürürlükte kalan anlaşma Kiliseye bir nefes aldırmışsa da onu aynı zamanda devletin kontrolüne de almıştır. Devlet, özellikle din adamlarının maaşlarını ödemesi ve piskopos atama işlerini üzerine almasıyla kilise üzerindeki otoritesini sağlamlaştırmıștır. Bununla birlikte, 1814 tarihinde anlaşmanın güncellenmesiyle Katoliklik, resmi din olarak kabul edilmiş ancak 1830 tarihinde yeniden güncellenen anlaşmayla resmi din olarak değil Fransız vatandaşlarının çoğunun dini olarak tanımlanmıştır (Kuru, 2011: 144). Bu alternatif oluşturamamanın yarattı̆̆ı boşluğun Katolik Kilisesi tarafından değerlendirildiği ve özellikle eğitim alanında devlet ile kilise arasındaki rekabette dengenin kilise lehine değiştiği görülmektedir. 1848 İhtilali ve ardından 1850 tarihli Falloux Kanunu Kilisenin eğitim üzerindeki etkinliğini pekiştirmiştir. Dolayısıyla 19. yüzyıl Fransa'sı iki zıt kutubun, yani din karşıtı Cumhuriyetçiler ile papa otoritesini yücelten Katoliklerin iktidar mücadelesine sahne olmuştur. Bu döneme kadar Fransa bir tür teokratik düzeninin etkisi altında varlığına devam etmekteydi. Papa IX. Pius 1864 tarihinde modern zamanların başlıca yanlışlarına ilişkin kilisenin kınadığı bir Hatalar listesini (Syllabus errorum) yayınladı. Buna göre Roma'nın nihai üstünlüğünü reddeden veya tanımayan her kamu yasası kınanmaktaydı. Papa gerektiğinde zor kullanarak, Fransız 'yasa ve geleneği'ne ilişkin herhangi bir konuda dinî müdahalede bulunma hakkına sahip olduğunu ileri sürmekteydi. Ayrıca, Kilisenin devletten ayrı olması gerektiği düşüncesi ile bireylerin inançlar ve dinler arasında dilediğini tercih etme özgürlüğüne sahip oldukları düşüncesi de reddedilip kınanan fikirler arasındaydı (Saunders, 2008, 153; Kuru, 2011, 142-145). Kilisenin bu konumu 1870'de ilan edilen Üçüncü Cumhuriyetle birlikte sona ermiştir. Yetmiş yıllık (1870-1940) bir zaman periyodunu kapsayan bu dönemin temel özelliklerinden biri, dini ve kurumlarını kamusal alandan dışlamaya yönelik bir politikanın takip edilmesiydi.

Dinî dernekler açısından bu çerçeveden bakıldı̆̆ında, dönemin Fransa'sında gerek toplumsal alanda sahip oldukları nüfuz gerekse maiyetlerindeki mal varlıklarıyla 
onların kamusal alanın en etkili aktörleri arasında oldukları görülmektedir. Önceki düzeni simgelemeleri ve o düzenin taşıyıcı unsurları arasında yer almaları Cumhuriyetçi elitin kurmak istediği yeni düzende yer almaları bir yana bir tehdit olarak algılanmalarına neden olmaktaydı. İște Fransa'da derneklere ilişkin çıkarılan yasa bu iklimde gündeme gelerek 1901 tarihinde meclisten geçti ve din karşıtı Cumhuriyetçilerle Katolikler arasında militanca bir çatışmanın başlamasına neden oldu (Stone, 2000 , 112). Yasa, her ne kadar dinî kurumları bütünüyle yasaklamasa da onları yeniden düzenlemeye ve kontrol altına almaya yönelik bir girişim içermekteydi.

Yasanın mimarlarından Waldeck-Rousseau, dinî cemaatlerin amacının bireyi geliştirmek olmadığını savunmaktaydı. Ona göre bu tür yapılar, bireye herhangi bir fayda sağlamadığı gibi onların kişiliğini cemaat yapısı içinde eritip baskı altında tutmaktan başka bir şey yapmamaktaydılar. Waldeck-Rousseau, cemaatleri bireysel özgürlük ilkesini görmezden geldikleri için tehlikeli olarak nitelendirmekteydi. Ancak meselenin siyasi bir tarafı da vardı ve bu, özellikle de cemaatçi öğretmenlerin kendi cemaatlerine kazandırmak istedikleri gençlere öğretilerini aşılamaya çalışmaları üzerinden Fransız egemenliğinin yıkımı ve Fransız vatandaşlarının özgürlüklerinin tasfiyesi olarak görülmekteydi. Waldeck-Rousseau bu şekilde genç nesillerin birbirileriyle karşlaşacakları güne kadar birbirilerini tanımayan bir toplumsal durumun ortaya çıktığını ve bu durumun toplumu bölücü bir niteliğe sahip olduğunu düşünmekteydi (Saunders, 2008, 154).

Saunders'a göre (Saunders, 2008, 155), Waldeck-Rousseau için mesele, basit bir din yanlısı veya karşıtlığı meselesi değildi. Mevcut dernek yapısında, dernek özgürlüğü ile uyum içinde olmayan birtakım sözler veya yeminler dayatılmaktadır. Waldeck-Rousseau senatoda yaptığı konuşmada, cemaat üyeliğinin bireysel haklara yabancılaşmaktan başka bir şey olmadığını ifade etmişti. O, cemaat ismi ile bilinen yapıların itaat, yoksulluk ve saflık yeminleri yapılmadan oluşmadığını savunduğu konuşmasında bu yeminlerin içeriğiyle ilgili şu ifadeleri kullanmıştı:

$\mathrm{Bu}$ yeminlerden bir tanesine göre, siz kendinizi dünyevi olarak kabul edilen çkarlardan; mülkiyet hakkına, başka bir ifade ile ülkenizin refahı için çalışmaya dayalı çkarlardan kesinlikle soyutlarsını.

Bu yeminlerden bir diğerine göre, siz kendinizi teologların ikincil kaygı diye isimlendirdikleri şeyden azade kllarsını. Bu kaygı, bir aileye sahip olmak, bu aileye ait olmak ve her şeyin üstünde bu aile için yaşamaktır.

Itaat yemini ile ise, bu yeminle sana doğal olarak görüneni yaparsin, ancak bu bana insan kişiliğinin kesin reddi olarak görünür. Ben diyorum ki, bunu bir avukatın dilini kullanarak değil, 'bir insan kişiliğinde kendini Tanrıya hibe etme' dersini veren kişilerin ifadelerini takip ederek yaparsın.

Şimdi sahip olduklarını düşünmeni ve hayatta kalmanı sağlayan kişiliğinden soyunduğunda, sorarım sana: bu kişilikten geriye ne kaldı? (Saunders, 2008, 155).

Dolayısıyla Waldeck-Rousseau'ya göre, kişi bir cemaate üye olduğunda cemaat yapısı kişinin temel bir özgürlük olarak görülen, kendi kararlarından sorumluluk almaya ilişkin bireysel kapasitesinden vazgeçmesine neden olmaktaydı. Bu nedenle 
devlet burada vatandaşını bu tür zararlı yapılardan koruma görevinin gerektirdiği bilinçle hareket etmekteydi. Yani yasa koyucu, gerçekleştirilen düzenlemeyi bireyi birey yapan özelliklerine kast eden, onu özgürlüğünden alıkoyan bir güce karşı bireyi özgürleştiren bir adım ve devletin de bir yükümlülüğü olarak meşrulaştırma eğilimdeydi. Bununla birlikte, bu yasa bağlamında, yönetici elitin meselenin sadece bireysel boyutuyla ilgili olmadığı, genel resmin içinde konunun devr-i sabık'ı temsil eden anlayışla cumhuriyeti temsil eden anlayışın kamusal alana sahip olmak için uzun zamandır kültürel, siyasal ve toplumsal alanlarında yürüttükleri iktidar mücadelesiyle ilgili olduğu da açıktır. Dolayısıyla meselenin kültürel, tarihsel ve teo-politik boyutlarının göz ardı edilmemesi gerekmektedir.

Dernekler Kanununun gerekçelendirilmesine ilişkin ortaya konan anlayışa değindikten sonra yasanın içeriğine bakmakta fayda vardır. Bu yasa incelendiğinde onun iki farklı bölümden oluşturulduğu görülmektedir. Yasanın, 1 ila 12. maddelerini kapsayan ilk bölümü vatandaşların özgür bir şekilde herhangi bir izne ihtiyaç duymaksızın dernek kurma koşullarını yaratmış, dernek özgürlüğünü garanti altına almıştır. Burada devlet özel alandan çekilmek suretiyle vatandaşların serbest bir şekilde dernek kurma üzerindeki mevcut gücünden feragat etmiştir. I. Napolyon döneminde bu tür konularla ilgili çıkarılan yasanın 291. maddesi şu şekilde düzenlenmişti: Hükümetin rızası ve kamu otoritelerinin topluma dayatmaktan hoşnut olabilecekleri koşullar dışında, her gün veya belirli günlerde bir takım dinî, edebi, siyasi vb. konuları ele almak amacıyla bir araya gelip üye sayısı 20 kişiden fazla olan hiçbir dernek kurulamaz (Klein, 1904, 247). Dernekler Kanunu ile bu zorunluluk ortadan kaldırılmış Fransız vatandaşları, herhangi bir koşul ve sınırlama olmaksızın dernek kurma hakkına sahip olmuşlardir.

Ortalama vatandaşa ilişkin özgürlükçü düzenlemelere imza atan 1901 Kanununun 13 ile 18 arasındaki maddeleri ise dinî cemaatler için yeni bir düzenleme getirmiştir. Klein'e göre $(1904,248)$, yasanın dinî derneklerle ilgili kısmı "Napolyon yasasından bile daha tiranca düzenlenmiştir." Buna göre dinî cemaatler için dernek kurma hükümetten izin alma şartına bağlanmaktaydı. Başka bir ifadeyle, dinî dernekler "faaliyet gösterecekleri koşulları belirleyen bir yasa tarafından verilen yetkilendirme olmaksızın" kurulamaz ve bu yetkiyi aldıklarında da "yetkili organlar tarafından verilen kararnamenin dışına çıkarak herhangi bir yeni kuruluş kuramazlar." Yasa yürürlüğe girdiğinde dernekleşmek için izin almayan cemaatler yasadışı olarak kabul edilecekti. Devletin hali hazırda yetki vermediği cemaatler yasanın yürürlüğe girmesinden itibaren üç ay içinde resmi onay için müracaat etmek zorundaydılar. Buradaki amaç, devletin sivil yönetimin amaçları için ayırdı̆̆ı nötr alana artık dinî cemaatlerin müdahalesini önlemektir. Devlet, bir taraftan bireylere dernek kurmak için izin verirken diğer taraftan ise 'dinî kuşatmaya' karşı kamusal alanı korumaya yönelik bir tedbir almaktayd1 (Stone, 2000, 112; Saunders, 2008, 155).

Yukarıda da ifade edildiği üzere, eğer cemaatler bir dernek kuracaklarsa bunun için yasal mercilerden yetki almak zorundaydılar. Yetki aldıklarında ve derneklerini 
kurduklarında da kendilerini sağlama almış olmuyorlardı. Çünkü devlet gerek duyduğu takdirde, bir hükümet kararnamesiyle onları feshetme yetkisine sahipti. Kurulmak için izin almak zorunda olan her dernek her zaman yöneticilerin keyfi uygulamalarına maruz kalabilmekteydi. Bu çerçevede yasanın 13. maddesi açıktır: "Bir cemaatin dağıtılması veya herhangi bir Kuruluşun kapatılması Bakanlar Kurulunun kararnamesiyle belirlenebilir."

Gerekli izinleri alabilmek için bir cemaatin takip etmesi gereken uzun bir prosedür bulunmaktaydı. Yasanın 15. maddesine göre, dinî cemaatler dernek kurabilmek için kamu görevlilerine gelir ve giderlerinin tam bir hesabını yapıp sunmaları ve istenildiği her anda hazırda tutmaları, tüzel veya özel olmasına bakılmaksızın tüm mal varlığı değerinin eksiksiz bir şekilde ifade edilmesi, üyelerinin her birinin adı, yaşı, geçmişte ve şimdi yaptıkları mesleklere ilişkin eksiksiz bir bilgilendirme kaydı gibi adımlar bu prosedürün gereklerinden bazılarıydı. Üstelik tüm bunlar yerine getirildikten sonra bile gerekli iznin verileceği garanti değildi. Gerekli izinler alınmadan bir dernek kurulması durumunda ise üyelerden her biri beş bin franka kadar para cezası ve bir yıla kadar hapis cezasına çarptırılacaktı. Aynı cezalar, herhangi bir Cemaat üyesine çalışma ortamı sağlayacak bir imkâna izin veren herkese verilebilirdi. Bu durumda derneğin kuruculuğunu ya da direktörlüğünü üstlenen kişiler ise bu cezaların iki katı kadar cezalandırılabilirdi.

Cemaatler ile devlet arasında okul, kolej, yurt, hastane ve her türlü kamu kurumları için anlaşmalar olmasına rağmen bundan böyle onlar yok hükmünde olacaktı ve cemaatler yukarıda ifade edilen bütün yükümlülükleri yerine getirmek zorundaydılar (Klein, 1904, 248). Bütün bunlara rağmen, eğer cemaatlerin dernek kurmak için izin alma talebi reddedilirse, onlar feshedilecek ve malları kamulaştırmak suretiyle tasfiye edilecekti. Eğer tasfiye harcamaları karşılandıktan sonra bir şey kalmışsa hükümet 'uygun gördügü' cemaat üyesine onları, belki, verebilirdi (Madde 18).

İzin talepleri reddedilen cemaat üyeleri ya yaşamak için sefalet içinde dilencilik yapacak ya da göç edeceklerdi. Çünkü bu kurumlardaki insanların büyük bir çoğunluğu öğretmendi ve yapabildikleri tek şeyi yapmaktan alıkonulmuşlardı. Yasanın 14. maddesine göre "ne kimseye bir eğitim kurumunu yönetmek için izin verilir, ne de eğer izin verilmemiş bir DinîCemaate aitse kimsenin orada eğitim verilmesine izin verilir." Bu yasayı ihlal eden herkes, yukarıda ifade edildiği gibi, para ve hapis cezasına çarptırılır ve kuruluş bu durumdan dolayı kapatılabilir. Yani hükümet dinî cemaatler söz konusu olduğunda istediği her türlü uygulamayı yapabilecek durumdaydı ve bunun hukukî temelini de 1901 Dernekler Kanununu çıararak elde ediyordu.

Yasanın mimarlarından Waldeck-Rousseau, dinîbir dernek kurabilmek için yetkili mercilerden izin alma prosedürüne cemaatlerin çoğunun rıza göstereceğini ve pek azının bu konuda direnç gösterebileceklerini düşünmekteydi. Bu konuda direnç 
göstermek ise yasaya aykırı davranmakla nitelendirilebilmekteydi. Bu nedenle yasaya intibak etmekte başarısız olan bir takım dinî cemaatler Ekim 1901 tarihinde feshedildiler (Saunders, 2008, 156).

Anlaşılacağı üzere, 1901 Dernekler Kanunu dinî cemaatlere karşı oldukça sert yaptırımlar içermekteydi. Ancak yasanın uygulanma biçimi sertlikte metni çok daha geride bırakmaktaydı. Klein (1904, 249), bu yasanın çok kurnazca, keyfi ve illegal bir şekilde uygulandığını, öyle ki Waldeck-Rousseau'nun bile yasanın dışına çıkıldığı ve tamamen çarpıtıldığını Senatoda ifade etmek zorunda kaldı̆̆ını ifade etmektedir.

Fransa'da, özellikle, dernekler hakkındaki bu yasanın çıkarıldığı 1901 ile 1904 tarihleri arası, cumhuriyetçi 'ilerleme'nin Katolik Kilisesi aleyhine geliştiği bir dönem olarak anılmaktadır. Bu dönem din karşıtı radikaller için seküler aklın, batıl inançlar ve günah çıkarma karanlığına karşı devam edegelen mücadeleden zaferle ayrıldı̆̆ı bir dönem olarak nitelendirilmektedir. Onlar açısından bu zaferle dini, kamusal alandan nihaî olarak söküp atmak, artık imkânsız bir hayal değildi. Din karşıtı eğilimin iktidarda bulunduğu bu iklimde 1902 tarihinde Devlet Konseyi, bütün kurumların din eğitimi için kamu yetkililerinden önceden izin alması gerektiği kararını aldı. Bu değişikliğin nedeni, Waldeck Rousseau'nun yerine geçen ve ondan çok daha radikal bir din karşıtı olan Emile Combes'in anlayışıydı. Combes ile birlikte, 1901 Dernekler Kanunu, sınırlarının dışına çıkılarak uygulanmıştır. Çünkü gerekli izinlere sahip olmasına rağmen, dinî cemaatlerin işlettiği yüzlerce okul Combes tarafından kapatılmıştır. 27 Ocak 1902'de Devlet Konseyi, herhangi bir dinî cemaatin, daha önce yetkilendirilmiş olsa bile, yeni bir kurum kurmak istediği her seferde izin almanın gerekli olduğunu ilan etmiştir. Altı ay sonra bu kez başbakan olarak görev yapan Combes, 1901 Kanunundan önce yetkilendirilmiş dinî cemaatlere ait okulların uygun durumda olmadığına hükmetmiş ve onlardan üç bin tanesini kapatmıştır (Klein, 1904, 250).

Yetkilendirilmiş cemaatlerin başına bunların geldiği bir ortamda, diğerlerinin rahat hareket edemeyeceği aşikârdı. Yetki için müracaat eden ve tüm üyelerinin ve mal varlıklarının bir listesini yetki organına veren cemaatler arasında bir karışıklık, anlaşmazlık ve ihtilaf durumu ortaya çıkmıştı. Papanın da tavsiyesine uyan çoğu Piskopos ve liberal seküler çevre yasaya boyun eğmeye ve dernek kurmak için gerekli olan yetkiyi alabilmek için gerekli adımları atmaya razı olmuştu. Cizvitlerin içinde bulunduğu bir grup ise hükümetin kendileri için tuzak kurduğunu ve bu oyuna gelmektense kendi iradeleriyle dağılmayı tercih edeceklerini ilan etmişti. Bu adım onlara, "düşmanca" bir tavır içinde olan yetkililere hesap vermeksizin, kendi üyelerini dağıtma, hayır kurumlarını kapatma ve mal varlıklarını kullanma olanağını sağlamıştı. Gelişmeler bu az sayıdaki cemaatlerin yaptıklarının doğru olduğunu göstermişti. Çünkü kendilerini hükümetin insafına bırakanlar ve dernek kurmak için yetki almaya zorlananların talepleri reddedilmişti (Klein, 1904, 251).

Combes hükümeti, öğretmenlik mesleğini daha önce izin alınmış dinî okullar da dâhil dinî tarikat üyelerine yasaklamıştı. Artık devlet tarafından maaşları ödenmeyen yaklaşık 30.000 Katolik din adamı eğitim-öğretim faaliyetinden uzaklaştırılmıştı. 
Nihayet Combes'in 25 Temmuz 1904 tarihli yasası ile Fransa Cumhuriyeti tek taraflı olarak papalıkla diplomatik ilişkilerine son vermişti. Gelişmeler bunlarla da sinırlı kalmamış, hükümet dernek kurmak için yetki alma talebinde bulunan cemaatlerin taleplerini, büyük oranda, reddetmişti (Saunders, 2008, 157).

1901 Kanunu dinî cemaatlerin dernek kurabilmeleri açısından son derece ağırlaştırılmış koşullar getirmesine rağmen, hükümetin bu yasanın dahi sınırlarını ihlal etmekten geri durmadığı anlaşılmaktadır. Söz gelimi, meclise gelen yetkilendirme taleplerinin her birinin ele alınıp karara bağlanması gerekirken, Meclis tam aksi bir pratiğe sahne olmuştur. Hükümet elini çabuk tutmak istediği için Meclis de hızlı bir şekilde ilerlemek ve müracaatları da blok halinde reddetme eğilimi göstermişti. Bu ortamda cemaatler, ‘eğitim veren', ‘vaaz veren' ve ‘ticaret yapan' şeklinde üç kategoriye ayrılmıştı. Her kategori herhangi bir detaya girmeden ve cemaatlerin büyük çoğunluğunun Meclis tartışmalarında ismi bile anılmadan oylamaya tabi tutularak talepleri reddedilmişti. Klein'ın aktardığına göre (Klein, 1904, 252), bizzat Waldeck-Rousseau ve onun gibi düşünen bazı Meclis üyeleri eğer kanun en başta bu şekilde anlaşılmış olsaydı onun asla kabul edilmeyeceğini ifade etmek durumunda kalmışlardı.

Sonuç olarak, yetkilendirme müracaatında bulunan cemaatlerin talepleri blok halinde reddedilmişti. Bu durum ise, hükümetin bu yasa ve onun prosedürüyle kendilerine tuzak kurduğunu bu nedenle de tuzağa düşmektense kendi iradeleriyle da$\breve{g}$ glmayı tercih eden cemaatleri haklı çıkarmıştı. Yetkilendirme müracaatında bulunanların durumu, müracaat etmeyenlere göre çok daha kötüydü. Çünkü bu talepte bulunmayan cemaatler üyelerini ve mal varlıklarını ifşa etmemekle idari sıkıntılardan büyük oranda kurtulmuşlardı. Diğerleri ise ellerindeki hiçbir şeyi kurtaramamışlardı. Yetki talebi sırasında isimleri ifşa olduğu için üyeleri birer birer kınanmış ve Fransa'da var olmaları neredeyse imkânsı hale gelmiști (Klein, 1904, 253). Böylece, 1901 Dernekler yasasıyla Fransa'da dinî kurumların toplumsal alanda faaliyet yürütebilme kabiliyetleri büyük oranda sınırlandırılmıștır. Devleti yöneten Cumhuriyetçi elit bu ve benzeri düzenlemelerle devleti toplumsal alanın tek aktörü haline getirmek istemiştir. Bu ise dinden arındırılmış bir kamusallık ve eğitim alanı dizayn etmek anlamına gelmektedir. Öte taraftan yapılan düzenlemeyle dinî alan devlete bağımlı hale getirilmiştir.

\section{Tekke ve Zaviyeler Kanunu}

Cumhuriyet'in ilanıyla beraber toplumsal hayatın yeniden ve başka bir perspektifle düzenleme girişimi, Osmanlı'dan devralınan toplumsalda önemli bir yere sahip olan tekke, zaviye ve türbelerin kaldırılmasını da kapsamıştır. Siyasal elitlerin, tasavvurları doğrultusundaki yeni toplumsal düzenlemelere girişebilmek ve onlara meşruiyet kazandırabilmek için, genellikle koşulların ve gerekçelerin olgunlaşmasını bekleme eğiliminde olmaları bilinen bir durumdur.

Bu bağlamda, Türkiye Cumhuriyeti'nin kurucu siyasal eliti açısından tekke ve zaviyelerin kapatılması konusuna bakıldığında, 'muasır medeniyet' idealine uygun 
bir toplumsal düzenin hedeflendiği ve bunun deklare edildiği görülmektedir. Dolayısıyla inanç alanının ve geleneklerin hâkim olduğu bir toplumsal tasavvur yerine lâdinî, akılcı, bilimi esas alan seküler bir toplumsal düzen inşa etme anlayışı temel bir hedef olarak ön plana çıkmaktaydı. Modernleşme eğilimleri, bilindiği üzere, Cumhuriyetle birlikte değil Osmanlı'da Tanzimat'la birlikte ortaya çıkmıştır. Osmanlı'daki modernleşme yöntemi tadil edici bir niteliğe sahipken; Cumhuriyet modernleşmesi devrimci bir karakterle eski toplumsal düzenin yerine yepyeni ilke ve prensiplere dayalı bir düzeni tavizsiz bir biçimde gerçekleştirme kararlılığını ortaya koymaktaydi.

Yeni rejim elitleri, bu yeni toplumsal düzeni kurarken Osmanlı'dan gelen, eski düzenin ruhunu yansıtan dolayısıyla yeni toplumsal düzenin özelliklerini ve ihtiyaçlarını karşılamak bir yana onunla zıt kutuplarda seyreden kurumların devam etmemesi gerektiğini düşünüyorlardı. Tarikatlar ve onların faaliyetlerini büyük ölçüde gerçekleştirdikleri tekke ve zaviyeler bu kurumlar arasında başı çekmekteydi. Yeni rejim açısından bu kurumlar batıl inanç ve hurafelerin kaynağı oldukları gerekçesiyle sakıncalı görülmekteydi. Bu durum ise yerleștirilmekte olan yeni rejim için bir tehdit niteliği taşımaktaydı çünkü aklı ve bilimi esas alan yeni rejim için "batıl inanç", "hurafe" ve bunlara kaynaklık eden mekânların varlığı kabul edilemezdi. Bu kurumların, aynı zamanda, rejim karşıtı çevrelerin toplanıp faaliyet yürütebileceği bir odak olma potansiyeline sahip oldukları da varsayılmaktaydı. Zaten kapatılma gerekçeleri arasında onların sadece batıl inanç ve hurafeye kaynaklık etmeleri değil aynı zamanda rejim karşıtı muhalefetin örgütlenebileceği mekânlar olmaları ihtimali ve potansiyeli de sayılmaktadır (Subaşı, 2004, 84).

1925 tarihindeki Şeyh Said İsyanı, zaten kapatılmak istenen tekke ve zaviyelerin ilgası için ihtiyaç duyulan gerekçeyi sağlamış görünmektedir. Yeni kurulan düzende, eski dünyayı temsil eden tekke ve zaviyelerin yerine getirebileceği herhangi bir fonksiyonunun olması düşünülemezdi. Çünkü Cumhuriyet'in üzerine oturtulduğu temel, bu tarz kurumlara izin vermeyen çağdaş Batı perspektifli bir mahiyete sahipti.

Bu tür bir iklimin etkili olduğu bir ortamda; tekke, zaviye ve türbelerin kapatılması konusu Meclis gündemine getirilmişti. Ancak bu dönem, sadece tekke ve zaviyelere ilişkin değil sosyo-kültürel hayatın başka alanlarında da yeni düzenlemeler yapma girişimlerine sahne olmuştur. Büyük tartışmalara neden olan şapka kanunu bu girişimlerden bir tanesi olarak ortaya çıkmıştır. Dolayısıyla tekke ve zaviyelerin kapatılması ile ilgili yasa görüşmeleri, şapka kanunu görüşmeleri sırasında yapılan aleyhte konuşmaların etkisinde başlamıştır. Kanun gerekçesinde, şapka kanunu nedeniyle çıan ve "irticaî” olarak nitelendirilen olaylar gündeme getirilerek bunların siyasi maksatlar için kullanılmaya müsait olduklarının tespit edildiği ve bu nedenle de İstiklal Mahkemeleri'nin görev yaptıkları bölgelerdeki tekke ve zaviyeleri yasakladığı ve Ankara İstiklal Mahkemesi'nin de bu konuda hükümetin dikkatini çektiği ifade edilmekteydi: 
Tekkeler ve zaviyeler gibi İslam dininin zorunlu kılmadığı kuruluşlar hak yolundan sapmışlar elinde, düşüncelerin karışımına ve siyasi amaçların desteklenmesine ne kadar elverişli olduklarını, mal ve canca birçok fedakârlıklar gerektiren son gericilik olayı açıkça anlattı, uyanıklık yarattı, vatan ve devletin esenliği ve huzuru için kuşkulananların dikkatini çekti. Doğu İstiklâl Mahkemesi’nin bu nedenle kendi yargı çevresindeki tekkelerin ve zaviyelerin kapatılmasına karar verdiği bilinmektedir. Ankara İstiklâl Mahkemesi de tekkelerin ve zaviyelerin kapatılması gereğinde Hükümetin dikkatini çekmiştir. ${ }^{1}$

Buna göre tekke ve türbeler, buralara giden pek çok masum vatandaşın dinî eğilimlerini istismar etmekte, ulemalık nüfuzundan faydalanarak halkı kötü emellerine alet etmektedirler. Bu nedenle bunların Cumhuriyette varlıklarına devam edemeyecekleri görüşü ileri sürülmekte, sebep olarak da çağdaş ve medeni memleketlerde bu tür kurumlara yer olmadığı belirtilmektedir.

Dolayısıyla tekke ve zaviyelerin kapatılmasında, aslında birbirileriyle bağlantılı iki nedenden söz edilebilir. Yasa görüşmelerinde ileri sürülen, bu tür kurumların siyasi amaçlara yönelik faaliyet yürütmeleri, yeni rejimin kodlarıyla örtüşmemeleri nedeniyle ona karşı muhalefet odakları olma potansiyelleri bu nedenlerden ilki ve esaslı olanını oluştururken, onların hurafe ve batıl inançların kaynağı olması ve dinî nüfuzlarından faydalanarak insanları kendi menfaatleri için kullanmaları ise ikinci bir neden olarak karşımıza çıkmaktadır. Kurucu siyasal elitin liderliğini yapan Atatürk de, bu durumu teyit eder nitelikte, 30 Ağustos 1925 tarihinde Kastamonu'da yaptı̆̆ konuşmanın ilgili bölümünde şu ifadeleri kullanmaktadır:

Mevcut tarikatların gayesi kendilerine tâbi olan kimseleri dünyevîve mânevi olan hayatta mazharı saadet kılmaktan başka ne olabilir? Bugün ilmin, fennin, bütün şümuliyle medeniyetin muvacehei şulepaşında filân veya falan şeyhin irşadiyle saadeti maddiye ve maneviye arayacak kadar iptidaî insanların Türkiye camiai medeniyesinde mevcudiyetini asla kabul etmiyorum (Atatürk, 1997, 225).

Atatürk'ün bu ifadeleri, meselenin sadece bu kurumların o gün içinde bulundukları kötü durumla, yani insanları maniple etme ve kendi menfaatleri doğrultusunda kullanmakla alakalı olmadığını, gerçekte dizayn edilmek ve yerleştirilmek istenen yeni düzenin unsurları arasında onlara yer verilmeyeceğiyle alakalı olduğunu ortaya koymaktadır. Bu konuşmanın hemen devamında sarf ettiği "Efendiler ve ey millet, iyi biliniz ki, Türkiye Cumhuriyeti şeyhler, dervişler, müritler, mensuplar memleketi olamaz. En doğru, en hakikî tarikat, tarikatı medeniyedir. Medeniyetin emir ve talep ettiğini yapmak insan için kâfidir" (Atatürk, 1997, 225) şeklindeki sözler bu tezi destekler mahiyettedir.

Tekke ve zaviyelerin kapatılmasından önce, 3 Mart 1924 tarihinde kaldırılan Şeriyye ve Evkaf Vekâleti'ne ilişkin 429 Sayılı Kanun'un 5. Maddesi ile Devlet, ülke sınırları içerisindeki bütün cami ve mescitlerin yanı sıra tekke ve zaviyeleri de kontrol ve

1 Kanun teklifinin gerekçesi ve Meclisteki görüşmeler için bk. “TBMM Tutanak Dergisi”, t.s., Dönem II, C. 19 , s. $145,165,39,311,312,322$. 
denetimine almıştır. Kanunun bu maddesi şu şekildedir: “Türkiye Cumhuriyeti dâhilinde bilcümle cevami ve mesacid-i şerifenin ve tekaya ve zevayanın idaresine, imam, hatip, vaiz, şeyh, müezzin ve kayyumların vesair müstahdemin tayin ve azillerine Diyanet İşleri Reisi memurdur" (Şeriye ve Evkaf ve Erkanı Harbiyei Umumiye Vekâletlerinin İlgasına Dair Kanun 1924)

Dolayısıyla devlet bir taraftan bu tür kurumları kontrolüne alırken diğer taraftan onların varlığını da resmen tanımış ve onaylamış oluyordu. Ancak 1925 Şubat'inda gerçekleşen Şeyh Said İsyanıyla birlikte tekke ve zaviyeler, isyanda rolleri olduğu gerekçesiyle yeni rejim için sakıncalı kurumlar olmaya başlamıştı. Akabinde de Doğu'daki İstiklal Mahkemesi sorumluluk alanındaki tekke ve zaviyeleri kapattırmiştır.

Böylece, tekke ve zaviyelerin kanunla kapatılmasından önce, Takrir-i Sükûn Kanunu ile kendisine sınırsız yetkiler verilen İstiklal Mahkemeleri eliyle kapatılmaya başlanmıştır. Şeyh Said ayaklanması nedeniyle Diyarbakır'da çalışan Şark İstiklal Mahkemesi, Şeyh Said ve arkadaşlarına ilişkin verdiği kararda tekke ve zaviyelerin kapatılmasına da hükmetmişti. 29 Haziran 1925 tarihinde Mahkeme Başkanlığı, tekke ve zaviyelerin birer "menba-1 şer ve fesad" yuvası oldukları, mensuplarının kendilerine kutsal payeler vererek halkı kendilerine secde ettirdiklerinin tespit edildiği bu nedenle kendi il ve ilçelerindeki tekke ve zaviyelerin kapatılması için ilgili savcılıktan il ve ilçe yöneticilerine yazı göndermesini istedi (Aybars, 1995: 328).

Doğu İstiklal Mahkemesi'nin aldığı bu karar ve akabinde Mustafa Kemal'in konuyla ilgili söylemleri tekke ve zaviyelerin kapatılması için gerekli olan zemini temin etmiştir. Onların Türk inkılabının amaçladığı toplumsal düzenin ruhuna uygun olmadıkları ve yerine getirdikleri fonksiyonlara Türk toplumunun ihtiyacının bulunmadığı, ilerlemek, aydınlanmak ve gelişmek için ihtiyaç duyulan tek şeyin ilim ve fen olduğunu ifade eden Atatürk bu konuda şöyle demektedir:

Tekkeler de behemehal kapatılmalıdır. Türkiye Cumhuriyeti her şubede irşatlarda bulunacak kudreti haizdir. Hiçbirimiz tekkelerin irşadına muhtaç değiliz... Tekkelerin gayesi halkı meczup ve aptal yapmaktır. Hâlbuki halk meczup ve aptal olmamaya karar vermiştir (Daver, 1955: 164).

Aynı konuda, Nutuk'ta ise şöyle denmektedir:

Birtakım şeyhlerin, dedelerin, seyyitlerin, çelebilerin, babaların, emirlerin arakasından sürüklenen ve falcılara, büyücülere, üfürükçülere ve nüshacılara talih ve hayatlarını emanet eden insanlardan mürekkep bir kitleye medeni bir millet nazarıyla bakılabilir mi? Milletimizin hakiki mahiyetini yanlıs manada gösterebilen ve asırlarca göstermiş olan bu gibi unsurlar ve müesseseler yeni Türkiye devletinde, Türkiye Cumhuriyeti'nde idame edilmemeliydi; buna ehemmiyet vermemek ilerleme ve yenileşme namına en büyük telafisi imkânsız hata olmaz mıydı? Medeniyet tarikatı Türkiye şeyhler, dervişler memleketi olamaz, ölülerden yardım ummak medeni bir topluluk için lekedir (Daver, 1955: 164).

Doğu İstiklal Mahkemesi'nin tekke ve zaviyeleri Şeyh Said İsyanıyla ilişkilendirerek, bölge sınırları içerisinde faaliyet gösteren bütün tekke ve zaviyeleri kapattırması, akabinde Mustafa Kemal'in çeşitli vesilelerle onların kapatılması gerektiğini 
ifade etmesiyle tekke ve zaviyelerin ülke genelinde kapatılması için artık harekete geçilebilecekti. Bu çerçevede, ilk olarak, 2 Eylül 1925 tarihli Bakanlar Kurulu kararnamesi ile 773 tekke ve 905 türbe kapatılmıştır. Kararnameye göre, faaliyetlerine son vermeleri kaydıyla şeyhler ölünceye kadar tekkelerinde kalabilecek ve bu süre boyunca maaş alabileceklerdi. Tekke, zaviye ve türbelerin kapatılması sonucu eğitim yapmaya müsait olanlar okul olarak kullanılacak, uygun olmayanlar ise satılacak ve elde edilen gelir köy okullarının yapımında kullanılacaktı. Bu çerçevede tekke, zaviye ve türbelerin kapılarına mühür vurulmuş, bunlar arasında sanat değerinin olduğu düşünülenlerin korunması görevi Millî Eğitim Bakanlığı'na verilmişti.

Ancak kararnameye karşı kimi çevrelerden gelen tepkiler üzerine konunun yasayla düzenlenmesine karar verilmiş ve 30 Kasım 1925 tarih ve 677 sayılı Tekke ve Zaviyelerle Türbelerin Seddine ve Türbedarlıklar ile Birtakım Unvanların Men ve İlgasına Dair Kanun kabul edilmiş, akabinde 13 Aralık 1925 tarihinde de Resmi Gazete'de yayınlanarak yürürlüğe girmiștir. Aynı tarihte Meclis tarafından alınan bir başka kararla Türk Ceza Kanunun 131. maddesi şu şekilde değiştirilmiştir:

Diyanet İşleri Başkanlığına bağlı dinî memurlar için Hükümetçe tespit edilen k1-

lı̆̆ı, yetkisiz ve izinsiz giyenler ile Türkiye Devletince verilmeyen ve müsaade edilmeyen nişanı takan ve kendi rütbesinin üstünde resmi elbise giyen ya da hiçbir rütbe ve memuriyeti olmadığı halde üniforma kuşananlar üç aydan bir yıla kadar hapsolunurlar.

Dolayısıyla yasaya uymayanlar hakkında cezaî müeyyideler getirilmiştir. Ayrıca, kapatılmış olan tekke, zaviye ve türbeleri yeniden açanların, yenilerini kuranların, tarikat törenleri için geçici de olsa yer verenlerin, yasaklanmış unvanları kullananların, ya da bunlara özel hizmetleri yapan ve bunlara ait elbiseleri giyenlerin üç aydan eksik olmamak üzere hapis ve elli liradan az olmamak üzere para cezası ile cezalandırılmaları öngörülmüştür.

Tekke ve zaviyelerin kapatılması 30 Kasım 1925 tarih ve 677 sayll kanunla kabul edilmiş ve 13 Aralı 1925 tarihinde 243 sayllı Resmî Gazetede yayınlanarak yürürlüğe girmiştir. Kanun metni şu şekildedir:

Türkiye Cumhuriyeti dâhilinde gerek vakıf suretiyle, gerek mülk olarak șeyhinin tasarrufu altında, gerek diğer suretlerle tesis edilmiş bulunan bilumum tekkeler ve zaviyeler, sahiplerinin diğer şekilde temellük ve tasarruf hakları baki kalmak üzere kâmilen kapatılmışlardır. Bunlardan mevzu usulü dâhilinde halen cami veya mescit olarak kullanılanlar ipka edilir. Bilumum tarikatlarla, şeyhlik, dervişlik, müritlik, dedelik, seyitlik, çelebilik, baballk, emirlik, naiplik, halifelik, büyücülük, üfürükçülük, falcılık ve gaipten haber vermek ve murada kavuşturmak maksadılla nüshacıllk gibi unvan ve sifatların istimaliyle, bu unvan ve sifatlara ait hizmet ifa ve kisve iksâsı (elbise giyilmesi) memnudur. Türkiye Cumhuriyeti dâhilinde selâtine (padişahlara) ait veya bir tarikata veyahut cerri menfaate müstenit olanlarla bilumum sair türbeler mesdut ve türbedarlıklar mülgadır. Kapatılıış olan tekke ve zaviyeleri veya türbeleri açanlar veya bunları yeniden ihdas edenler veya tarikat âyini icrasına mahsus olarak velev muvakkaten olsa bile yer verenler ve yukarıdaki unvanları taşıyanlar veya bunlara mahsus hizmetleri ifa 
veya klyafeti iksâ edenler üç aydan eksik olmamak üzere hapse ve elli liradan aşağı olmamak üzere para cezasına çarptırılırlar.

Kanunun yürürlüğe girmesi ile birlikte ülke sathındaki tüm tarikatlar yasaklanmış, tekke ve zaviyeler kapatılarak mallarına el konulmuştur. Bunun yanı sıra şeyh, derviş, mürid, dede, seyyid, çelebi, baba, emir, nakip ve halife gibi unvanların kullanılması ile tarikatlarda toplantı ve merasimlerin gerçekleştirilmesi de yasaklanmıştır. Ancak o tarihte yürürlükte bulunan 1924 Anayasasının 75. maddesi “din, mezhep, tarikat ya da felsefi içtihat” özgürlüğünü güvence altına aldığı için tarikatlara intisap etme serbestisi getirmekteydi. Dolayısıyla 677 sayılı kanun, 5 Şubat 1937 tarihinde "tarikat" kelimesinin metinden çıkartılmasına ilişkin değişiklik hükmüne kadar Anayasaya aykırı bir kanun olarak varlığına devam etmişti (Daver, 1955, 162; Lewis, 2008, 255).

Tekke, zaviye ve türbelerin kapatılmasına ilişkin kanun Meclis’te çeşitli şekillerde gerekçelendirilmiştir. Bunlar arasında dikkat çeken görüşlerden bir tanesi Rize mebusu Ekrem Bey'e aittir. Ekrem Bey bu kanunun önemli olduğunu, şeyh ve tekkelerin padişaha bağlılıklarını ifade ettiklerini, onların da padişah nazarında itibar gördüklerini vurgulamıştır. Kanun lehine söz alan mebuslardan Rasih Bey (Antalya mebusu) tekke ve tarikatların on, on bir asırdır sadece Türkiye Cumhuriyeti'ne değil bütün Müslüman memleketlerine zillet ve cehalet getirdiğini ileri sürmüştür (Sakall, 1994, 209).

Tekke, zaviye ve türbelerin kapatılması sürecinde dönemin basını, büyük oranda, iktidar elitinin yanında yer almış ve kapatılma gerekçelerini kendi sayfalarında detaylı bir şekilde işleyerek kanunun ilerleme ve medeniyet yolunda isabetli bir adım olduğunu ifade etmeye çalışmışlardır. Örneğin, İstanbul'da yayınlanan "Haftalık Mecmua" (1925) isimli yayın organının 14 Eylül 1925 (1342) nüshasında söz konusu yasa çıktıktan sonra konuyla ilgili bir makalede şöyle bir değerlendirmede bulunulmuştur ("Haftanın Sohbeti" 1925, 2):

İnkılab; manasız, lüzumsuz, muzır ocaklardan bir kısmını daha söndürdü. Milletin teceddüt savletlerine çelme takan tarikatlar, takyeler, türbeler kapandı. Fırıldak gibi döne döne i'tila hülyası besleyen Mevleviler, nar beyza haline gelmiş demirle dağlanan, keskin şişleri avurdlarına batıran korkunç rüfailer, îş û nûş (yiyip içme) ser hidayete irmeğe çalışan bektaşiler ... tarihe karıştılar... Takyeler, bir ibadethane değil bir tımarhane idi. Oraya aklı başında giren insanlar Toptaşındaki delileri hayrette bırakacak çılgınlıklar yapan birer mecnun haline gelirlerdi... Şimdi artık büyük Gazi'nin dediği gibi bir tek tarikat vardır: Medeniyet tarikatı... İnkılab takyeleri ve türbeleri kapatmakla çok hayırlı bir iş yapmışdır.

Tekke, zaviye ve türbelerin kapatılmasını dönemin basın dünyasından destekleyen bir başka örnek ise Ankara'da yayın yapan "Hakimiyet-i Milliye" isimli yayın organıdır. 3 Aralık 1925 tarihli nüshasında Ahmet Ağaoğlu (1925), “Tekke ve Zaviyelerin Seddi” başlıklı bir makalede yasayı destekleyici bir değerlendirme yaparken görüşlerini şu şekilde dile getirmektedir:

Millet çoktan beri tekye ve zâviyeler hakkında hükmünü vermişdi... Bizde tekye ve zaviyeler hizmet ve mahiyeti asliyelerini çoktan gaib etmişleridi. Bizde de bunlar ahlâken düşkün, vücuden malul ve aklen perişan olanların melcei olmuşlardır... Artık, muntazam bir devlet kurmuş, muntazam bir maarif, bir adliye, bir 
idare teşkil eden bir devletde bu gibi müesseselere yer verilmezdi... Bunlar sağ-

lam bir vücud üzerinde yapışan malul ve hasta varlıklardı.

Öte yandan; tekke, zaviye ve türbelerin kapatılmasını ön gören kanuna ilişkin tepkilerin genelde olumlu olduğu, olumsuz ciddi tepkilere pek rastlanmadığı bilinmektedir. Bunun için çeşitli nedenler sayılabilir. Örneğin artık "muasır medeniyet seviyesine çıkma" hedefinde olan bir toplumda bu tür kurumlara yer olmadığı yani laikleşme yolunda ilerleyen bir toplumda dine dayalı bu ve benzeri kurumlara ihtiyaç olmadığının kesin bir dille ifade edilmesi, aynı tarihlerde kılık-kıyafet ve şapka kanunlarının da çıkarılması ve gündemi ciddi bir şekilde işgal etmesi nedeniyle tekke, zaviye ve türbelerin kapatılması kanununun geri planda kalması ve en nihayet "Takrir-i Sükûn Kanunu” gibi bir kanunun yürürlükte olması nedeniyle tepki göstermenin çok ciddi bir bedel gerektirmesi gibi sebepler akla gelen ilk gerekçeler arasındadır.

Tekke, zaviye ve türbelerin kanunla kapatılması karşısında bir taraftan olayı soğukkanlılıkla karşılayan diğer taraftan şaşkınlık içinde, ama dönemin konjonktüründen dolayı sessiz bir şekilde karşılama gibi bir duruş söz konusu olmuştur. Burada dikkat çeken durum; tekke, zaviye ve türbelerin kapatılmasına ilişkin kanunla birlikte tarikat çevrelerinin uğramış olduğu statü kaybıdır. Bu gelişme ile birlikte bu çevreler maddi olanaklarının yanı sıra manevi saygınlıklarını da önemli ölçüde yitirmişlerdir (Kara, 1996, 14). Tekke, zaviye ve türbeler kapatılırken görevlilerin maaşlarının kesilmemesi yönünde bir karar alınmıştı ancak bu karar görevlilerin tamamını kapsamamıştır. Çünkü dini, politikaya alet etme suçundan yargılanan ve hüküm giyenlerin beş yıllık bir cezaya çarptırılmalarının yanı sıra maaşları da kesilmiştir. Bu tür kişiler ailelerinin geçimini sağlayabilmek için valiliklere başvurmuşlardır. Yeni şartlara uyum sağlamak mecburiyetinde olan tarikat mensuplarının bir kısmı okul ve camilerde kapıcılık yaparken, çoğunluğu ise zanaatkârlık yapmak suretiyle çeşitli alanlarda çalışmak zorunda kalmışlardır (Doğaner, 2006, 218).

Tekke, zaviye ve türbelerin kapatılması Takrir-i Sükûn Kanunun yürürlükte olduğu bir dönemde gerçekleşmiştir. Kapatılma işlemi özellikle jandarma tarafından yapılmakta ve kapatma işlemine ilişkin tutanaklar doğrudan İstiklal Mahkemesine gönderilmekteydi. Kapatılma işlemi esnasında birkaç küçük direnme eyleminin d1şında bir dirençle karşılaşılmaması İstiklal Mahkemesinin ve yürürlükteki Takrir-i Sükûn kanununun gücü ve etkinliğinin üst düzeyde olduğuna yorulmuştur (Aybars, 1995, 328). Çünkü bu kanun, bu kurumların kapatılmasına karşı verilecek tepkileri önceden bertaraf etme imkânını sağlamaktaydı. Bu sayede, Cumhuriyetin oluşturmak istediği düzende yer etmesi kabil olmayan eski dünyaya ait bu kurumların ilga edilmesini kolaylaştırmaktaydı.

$\mathrm{Bu}$ kurumların yeniden canlandırılmaması veya açılmaması için oldukça sert önlemler alınmış ve uzun bir süre boyunca açılmaları söz konusu olmamıştır. ${ }^{2} \mathrm{Bu}-$ nunla birlikte, bu kurumların kapatılması onlara olan ihtiyacı, dolayısıyla da yönelimi

2 Tekke, zaviye ve türbelerin kapatılmasına ilişkin yasanın gündemde olduğu zamanlarda, Atatürk her türlü türbenin kapatılacağını kesin bir dil ve taviz vermez bir üslupla Hamdullah Suphi’ye söylemiştir. 
bitirmemiştir. Tarikatlar varlıklarını devam ettirebilmiştir ancak mensupları genellikle 'irtica' ile birlikte anılır olmuştur. Bu nedenle düzen karşıtı herhangi bir hareket vuku bulduğunda verilen tepkiler genelde tekke, zaviye ve türbelerin kapatılmalarına gönderme yapmaktaydı. Örneğin 1935 tarihinde Bursa'da çıkan olayları sayfalarına taşıyan Cumhuriyet gazetesi 8 Mayıs 1935 tarihli nüshasında olayı "tekkeler kapatıldığ halde birer suretle dervişlik yapmak isteyen bazı safdillerin bazı cazibelere kapılmış oldukları" şeklinde vererek sorumluların yakalandığını belirtmiştir. Bir sonraki nüshasında ise olaya karışanların tarikatçı oldukları ve aralarındaki mektuplaşmalardan tarikatları ihya etmek istediklerinin anlaşıldığı ifade edilmektedir. Olayın akabinde CHP genel merkezi illere yolladığı genelgede Ramazan ayında Arapça Ezan okumak, sala vermek, gizli telkin için tarikat toplantıları tertiplemek gibi gerici hareketlere tesadüf edildiği, devrimi ve ileriye doğru gidişi koruma ve yaymakla görevli partililerin bu tür gerici hareketlere karşı uyanık olmaları konusunda uyarmıştır (Koçak, 2011, 241).

Kanunla birlikte tekke, zaviye ve türbeler sadece kapatılmamış aynı zamanda onların mal varlıklarına da el konulmuş ve devletin tasarrufu altına alınmıştır. Osmanlı imparatorluğu döneminde toprakların önemli bir bölümüne vakıfların sahip olduğu bilinmektedir. Vakıflar Genel Müdürlüğü'nün verilerine göre, Osmanlı İmparatorluğunun son dönemlerinde vakıflar arazinin yaklaşık dörtte birine sahipti. Bu dönemde, Mehmet Sait Paşa da hazırladığı raporda ülke arazisinin yarıdan fazlasının vakıfların mülkiyetinde olduğunu ifade etmektedir. 1925 tarihinde kapatılan tekke ve zaviyeler de önemli oranda arazi ve gayrimenkulün mülkiyetine sahipti. Bu durum onlara çok önemli bir ekonomik güç sağlamaktaydı ancak Cumhuriyet eliti onları uluslaşma sürecinin önünde bir engel olarak gördüğü için ekonomik güçlerinin ellerinden alınması ve mallarına el konulması gerektiğini düşünmekteydi.1924 tarihinde 429 Sayılı Kanunla Şer'iye ve Evkaf Bakanlığı'nın kaldırılıp yerine Vakıflar Genel Müdürlüğünün kurulması ve sonraki yıllarda bütçe kanunlarına konulan maddeler ve çıkarılan yasalarla devlet, vakıfların denetimini ve yönetimini eline almıştı 5.6.1935 tarih ve 2762 sayılı Vakıflar Kanunu, vakıfları adeta devletin bir parçası haline getirmiştir.

Bilindiği üzere, 3 Mart 1924 tarihinde Türkiye Büyük Millet Meclisi'nde üç önemli kanun kabul edilmiştir. Bunlar sırasıyla 429 sayılı Kanunla Şer’iye ve Evkaf Bakanlığı'nın kaldırılması, 430 sayılı Tevhidi Tedrisat Kanununun çıkarılması ve 431 sayılı Kanunla Hilafetin kaldırılmasıydı. Bu kanunlar tarikatlara hem siyasi hem ekonomik hem de eğitim alanında büyük bir darbe indirmiştir. Bu kesimler, siyaseten etkisiz hale getirilmelerinin yanı sıra ekonomik güçlerinin ve ellerindeki eğitim olanaklarının kamulaştırılmasıyla karşı karşıya kalmıştır. Tekke ve zaviyelerin kapatılmasına ilişkin kanunla birlikte, onların arazi ve taşınmazlarına el konarak evkaf müdürlüklerine bağlanmıştır. Bununla hem yeni dönemde olmaması gerektiği düşünülen

O, bunun o zaman için gerekli olduğunu çünkü bu tür kurumların istismar aracı haline geldikleri ve bu durum değişmedikçe de onların kapalı olacağını ifade etmiştir (Baydar, 1968, 171). 
bir kimliğin güçlenmesinin engellenmesi hem de bu kimliği besleyen ve onun varl1ğını devam ettiren ekonomik yapının zayıflatılması amaçlanmıştır. ${ }^{3}$

\section{Sonuç ve Değerlendirme}

Bu çalışma devletin toplumsal alan-din ilişkisini düzenleme politikaları çerçevesinde Fransa ve Türkiye'de gündeme gelen iki yasaya odaklanmaktadır. Burada bu iki yasanın birebir aynı olduğu iddia edilmemekle birlikte çalışma, iki yasanın benzer yönleri muhtevi olduğunu ve yasaların kurgulanmasında ortaya konan anlayışın ve gerekçelerin ortak özelliklere sahip olduğu noktasından hareket etmektedir. Genel olarak, Fransa'da 1789 Devriminden sonra devletin dinî alanı kontrol etmeye yönelik politikalar geliştirmesi, dinin kamusal alanın dışına itilmesi, din ile ilişkili unsurların kimi zaman akıl dışı, ilerleme karşıtı, hurafe, batıl inanç gibi nitelemelere konu edilmesi kimi zaman da ulusal egemenliği ve bütünlüğü tehdit edici bir unsur olarak görülmesi gibi durumların Türkiye Cumhuriyeti'nin ilk yıllarındaki yönetici elit için ilham kaynağı olduğu, iki ülkenin bu açıdan karşılaştırılabilir niteliklere sahip olduğu pek çok araştırmacı ve gözlemci tarafından vurgulanmıştır.

Öte yandan, gerek Fransa'da Kilise ve dinî derneklere, gerekse Türkiye'de tekke, zaviye ve tarikatlara karşı yürütülen mücadelenin asıl sebebi onları eski düzenin en güçlü ve ayrıcalıklı pozisyonlarından birine sahip olmaları ve Cumhuriyetçi projelerin önünde büyük bir engel olarak görülmeleridir.

Bu çerçevede her iki düzenleme ele alındığında, 1901 Dernekler Kanunu ile Tekke, Zaviye ve Türbelerin Kapatılmasına Dair Kanunu'nun hazırlanış sürecinde benzerlikler göze çarpmaktadır. Ancak, bu düzenlemeler anlayış bakımından yakın toplumsal düzenlemeler olsalar da, birbirinden farklı sonuçları beraberinde getirmiştir. Sözgelimi, Fransa'da 1901 kanunuyla kilise kökenli eğiticiler eğitim alanından bütünüyle uzaklaştırılırken, hatta onlar için ülkede yaşamaya devam etmek neredeyse imkânsız bir hal alırken, 1925 tarihli tekke, zaviye ve türbelerin kapatılmasına ilişkin yasayla birlikte bu kurumlarda bulunan görevliler maaş almaya devam etmiş ve çeşitli işlerde istihdam etme yolları aranmıştır. İki yasaya bu açıdan bakıldığında Türkiye'de söz konusu düzenlemeyi geçirmek isteyen yönetici elitin bu kurumlarda çal1şan kesime daha ılımlı yaklaştı̆̆ı görülmektedir.

Her iki düzenlemeyle alakalı dikkat çeken bir başka farklılık ise yasalardan sonra bu kurumların varlığını devam ettirip ettirmeme konusunda kendisini göstermektedir. Fransa'daki yasal durum, 1901 kanunundan sonra, de facto olarak neredeyse imkânsız hale getirilmiş ise de de jure olarak dinî cemaatlerin varlıklarına devam etmesine ve yasanın gerektirdiği prosedüre uyulması durumunda yenilerinin açılmasına olanak tanımaktadır. Tekke ve zaviyelere ilişkin kanununa bu açıdan bakıld1ğında, ne o dönemde mevcut olanların hizmetlerine devam etmesi ne de yeni tekke

3 Bu çerçevede ülke genelinde el konulan arazilerle ilgili detaylı bilgi için bk. (Vakıflar Genel Müdürlüğü, 1973) 
ve zaviyelerin, 1950 tarihine kadar bazı Türk büyüklerine ait olanlar ile sanat değeri bulunanların dışında, açılması mümkün olmuştur.

Buna mukabil, her iki yasal düzenleme benzer yönleri ile de ön plana çlkmaktadırlar. Öncelikle, kullanılan retoriğe bakıldığında gerek Fransa gerekse Türkiye'de bu yasal düzenlemeleri geçirmek isteyen elitin, din karşıtlı̆̆ı gerekçesiyle böyle bir düzenlemeye gitmediklerini ifade etme ihtiyacı içinde oldukları görülmektedir. Her iki durumda da yönetici elit vatandaşlarını karanlık çevrelere ve onların köhnemiş fikirlerine karşı korumak için bu düzenlemeyi meşrulaştırmaya gayret ettikleri anlaşılmaktadır.

Her iki ülkenin de siyasi elitleri, yapmak istedikleri düzenlemeler için uygun iklimi oluşturmaya çalışırken bu tür kurumların insanların dinî eğilimlerinden faydalanmaya çalıştıkları ve onları istismar ettiklerini belirttikleri görülmektedir. Fransa'da dinî derneklere ilişkin çıkarılmak istenen yasa gerekçelendirilirken dinîcemaat ve yapıların bireyin özgürlüğünü yok ettiği, cemaatlerin üyelerini bireysel haklarına yabancılaştırdığı, onları itaat, yoksulluk ve saflığa sürükledikleri için onların toplumsal birlik açısından da tehlike arz ettiği ifade edilmektedir. Türkiye'deki tekke ve zaviyelere ilişkin kanun açısından meseleye bakıldığında da benzer bir bakış açısına rastlanmaktadır. Gerek kanun çıkarılmadan önce gerekse çıkarılma sürecinde yönetici elitler benzer görüşler serdetmişlerdir. Bu kurumlar bir taraftan batıl inanç ve hurafelerin kaynağı olarak, diğer taraftan insanların inançlarını maniple eden, onları kendilerine "secde ettiren" yapılar olarak nitelendirilmenin yanı sıra rejim karşıtı muhalefetin potansiyel örgütlenme mekânları olarak görülmüştür. Ayrıca, her iki ülkede de kapatılmak istenen kurumların ulusal egemenliği yıkıcı bir rol oynamakla suçlanmaları ilgi çekici bir başka benzerlik olarak karşımıza çıkmaktadır.

Fransa'da prosedüre uymadan ya da prosedürün tamamlanması beklenmeden dinî bir derneğin kurulması durumunda üyeler para ve hapis cezalarına çarptırılırken, aynı cezaların cemaat üyelerine çalışma ortamı ve imkânı sağlayan başka herkese de verilmesi öngörülmüştür. Benzer bir durumla, Türkiye'de tekke ve zaviyelerle ilgili kanunun metninde de karşılaşılmaktadır. Burada da yasayla kapatılmış olan tekke, zaviye ve türbeleri yeniden açanlar veya yenilerini kuranlar ile bu tür kurumlarda gerçekleştirilen faaliyetler için yer temin edenlerin para ve hapis cezası ile cezalandıracakları ifade edilmiştir.

Fransa' daki cemaatlerin dinî dernek kurma talepleri reddedildiğinde tüzel kişilikleri feshedilip mallarına da el konulmaktaydı. Tekke ve zaviyelere ilişkin kanunun yürürlüğe girmesi ile birlikte Türkiye'de de benzer bir durum yaşanmış kapatılan tekke ve zaviyelerin mallarına el konulmuştur. Tekke ve zaviyeler kanunundan sonra tarikat çevrelerinin, Fransa'da 1901 Kanunu ile dinî cemaat çevrelerinin uğradıkları türden sert uygulamalar ortaya çıkmasa da hem toplumsal olarak statü kayıplarına uğradıkları hem de maddi olanaklarının yanı sıra manevi saygınlıklarını da önemli ölçüde yitirdikleri bilinmektedir. Dolayısıyla Fransa'da kilise ve dinî derneklerin sahip olduğu toprak ve mal varlığının Dernekler Kanunu ile el konularak kamulaştırılmasına benzer bir biçimde tekke, zaviye ve türbelerin kapatılmasılla birlikte Türkiye'de de gerçekleştirildiği görülmektedir. 
Fransa'da cemaatler dernek kurabilmek için devlet mercilerinden yetki almasına rağmen, devletin gerek duyması durumunda onları feshetme yetkisine sahip olmaları devlete bu konuda keyfi davranabilme kabiliyetini kazandırmış ve devletin bu keyfiyeti kullanma konusunda oldukça cömert davrandığı anlaşılmaktadır. Devlet, din karşıtı katı bir eğilimin iktidarında, dinî yapılara karşı keyfî davranmada hiçbir sınır tanımamış görünmektedir. Bu durum, özellikle Waldeck-Rousseau'nun yerine geçen Combes dönemi uygulamalarında çok daha açık bir biçimde kendini göstermektedir. Öte yandan, tekke ve zaviyelerin kapatılmasına ilişkin zikredilen sebepler birtakım olumsuzlukları dile getirmekle beraber, bu olumsuzlukların toplumun tarihinde ve sosyal hayatında yer etmiş olan bu kurumların kapatılması için yeterli gerekçeleri sağlamasından ziyade, bu tür kurumların yeni rejimin idealize ettiği toplumsal düzenin kodlarıyla uyum içinde olmaması ve olası karşıtlıkların merkez üssü haline gelmeleri öngörüsünden kaynaklandı̆̆ı görülmektedir. Dolayısıyla bunun d1şında ileri sürülen, sebeplerin daha çok yapılan eylemin meşrulaştırılmasına hizmet etmesi için üretildiği anlaşılmaktadır.

Sonuç olarak, her iki rejimin de kendisini yeni bir siyasi ve toplumsal sürecin öznesi olarak tanımlaması nedeniyle insanların düşünce ve davranış kalıplarını değiştirme iddiasında oldukları ve yeni bir insan tipini ortaya çıkarmaya çalıştıkları görülmektedir. Bu iddianın hayata geçirilmesinde problem yarattığı düşünülen unsurların etkisizleştirilerek bertaraf edilmeleri, her iki rejimde de yönetici elit için büyük bir önem taşımıştır. Böylece, her iki örnekte de devlet, yönetici sınıfın eliyle, toplumu kendi idealine uygun bir hale dönüştürmek, kendi tasvip ettiği niteliklere haiz bir toplumsal yapı yaratmak ve kendi normlarına uygun bir hiyerarşik düzen oluşturma çabası içinden hareket etmiş görünmektedir. Bu çabaların odaklandığı dinî alanın devletin kontrolü altına alınarak bağımlı kılınması, kamusal alanın makbul sayılmayan toplumsal taleplerden arındırılması için vazgeçilmez bir unsur olarak algılandığı anlaşılmaktadır.

$\mathrm{Bu}$ çalışmanın hazırlanma sürecinde bilimsel ve etik ilkelere uyulduğu ve yararlanılan tüm çalışmaların kay-

Etik Beyan / Ethical Statement

Yazar / Author nakçada belirtildiği beyan olunur/It is declared that scientific and ethical principles have been followed while carrying out and writing this study and that all the sources used have been properly cited.

Mesut Düzce

\section{Kaynakça}

Ağaoğlu, Ahmet. “Tekke ve Zaviyelerin Seddi”. Hâkimiyet-i Milliye. 03 Aralık 1925.

Antes, Peter. “Fransa'da Sekularizm ve Laiklik”. Din ve Devlet îlişkileri Farkh Modeller, Konseptler ve Tecrübeler. 9-16. Ankara: Konrad Adenauer Vakfi, 2003.

Atatürk, Mustafa K. Atatük’ün Söylev ve Demeçleri I-III. Ankara: Türk Tarih Kurumu Basımevi, 1997. Aybars, Ergün. İstiklâl Mahkemeleri Cilt I-II 1920-1927. İzmir: İleri Kitabevi, 1995. 
Baydar, Mustafa. Hamdullah Suphi Tanriöver ve Anıları. İstanbul: Menekşe Kitabevi, 1968.

Daver, Bülent. Türkiye Cumhuriyetinde Lâyiklik. Ankara: Son Havadis Matbaası, 1955.

Doğaner, Yasemin. “Toplumsal Alanda Yapılan Atatürk İnkılapları ve Etkileri”. Dünden Bugüne Türkiyénin Toplumsal Yapısı. Ed. Mehmet Zencikıran. 203-235. Ankara: Nova Yayınları, 2006.

“Haftanın Sohbeti”. Haftalık Mecmua. 14 Eylül 1925. https://dijital-kutuphane.mkutup.gov.tr/tr/periodicals/catalog/issue/41843.

Kara, İsmail. “Sonuç Yerine: Tekkeler Kapandı mı?” Dergah 16 (1996), 14-15.

Klein, Felix. "Religious Associations and the French Government"“. The North American Review 178 (1904), 246-256.

Koçak, Cemil. Tek-Parti Döneminde Muhalif Sesler. İstanbul: İletişim Yayınları, 2011.

Kuru, Ahmet. Pasif ve Dışlayııı Laiklik: ABD, Fransa ve Türkiye. Trc. Eylem Ç. Babaoğlu. İstanbul: Bilgi Üniversitesi Yayınları, 2011.

Lewis, Bernard. Modern Türkiye’nin Doğuşu. Ed. Çev Boğaç B. Turna. Ankara: Arkadaş Yayınları, 2008.

Sakall, Bayram. “Tekke, Zâviye ve Türbelerin Türk Toplumundaki Rolleri, Kapatılmaları ve Tepkiler”. Türkiye Günlüğ̈̈ 29 (1994), 202-217.

Saunders, David. "Anticommunautarisme and the Government of Religious Difference". Economy and Society 37/2 (2008), 151-171.

Stone, Judith F. "Anticlericals and Bonnes Soeurs: The Rhetoric of the 1901 Law of Associations". French Historical Studies 23/1 (2000), 105-128. https://doi.org/10.1215/00161071-23-1-103

Subaşı, Necdet. Gündelik Hayat ve Dinsellik. İstanbul: İz Yayıncıllk, 2004.

Şeriye ve Evkaf ve Erkânı Harbiyei Umumiye Vekâletlerinin İlgasına Dair Kanun. 429: § (1924). https://www.tbmm.gov.tr/tutanaklar/KANUNLAR_KARARLAR/kanuntbmmc002/kanuntbmmc002/kanuntbmmc00200429.pdf. “TBMM Tutanak Dergisi”.ts.

Vakıflar Genel Müdürlüğü. Cumhuriyet’in 50. Yllında Vakıflar. Ankara: Vakıflar Genel Müdürlüğü Yayınları, 1973. 